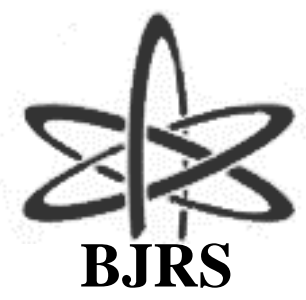
BRAZILIAN JOURNAL
$\mathrm{OF}$
RADIATION SCIENCES
09-01A (2021) 01-09

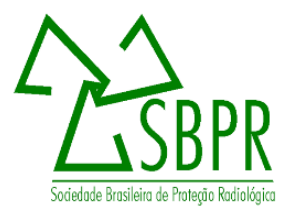

\title{
Total phenolic compounds of irradiated chia seeds
}

\author{
Chierentin $^{a}$ G.S., Teixeira ${ }^{a}$ B.S., Mastro ${ }^{a}$ N.L. \\ ${ }^{a}$ Instituto de Pesquisas Energéticas e Nucleares (IPEN / CNEN - SP), 05508-000, São Paulo, São Paulo, Brazil. \\ gabrielsouza_ch@hotmail.com
}

\begin{abstract}
Chia seeds (Salvia hispanica L.) is a good source of oil, protein, dietary fiber, minerals and polyphenolic compounds. In order to study the influence of the processing methods on the content of phenolic compounds, the objective of this work was to evaluate the effect of gamma radiation, doses 0 (control), 5, 10 and $20 \mathrm{kGy}$, on the total phenolic compounds extracted from chia seeds. Seeds were first defatted and extracts produced with proper solvents. Total phenolic content was determined according to Folin-Ciocalteu's method and the extraction solvents applied were ethanol $100 \%$, ethanol $70 \%$, ethanol $50 \%$, methanol $100 \%$, methanol $70 \%$ and methanol $50 \%$. When using ethanol $100 \%$, ethanol $70 \%$, ethanol $50 \%$, methanol $100 \%$ and methanol $70 \%$, the extraction yield was independent of the absorbed dose. With methanol 50\%, the irradiation process affected positively the total phenolic yield from of chia seeds. In general, the absorbed dose as well as the nature of the solvent affected the extraction yield, although in a limited manner.
\end{abstract}

Keywords: Chia (Salvia hispanica L.), phenolic compounds, food irradiation. 


\section{INTRODUCTION}

Chia (Salvia hispanica L) is an herbaceous plant of Lamiaceae family and that grown semiannually. Native from Southern Mexico and northern Guatemala [1, 2], chia is currently grown in Australia, Bolivia, Colombia, Guatemala, Mexico, Peru and Argentina. In Brazil, the regions of western Paraná state and northwestern Rio Grande do Sul state are the main producers. Inclusion of chia in the human diet contribute to human health due to their high content of essential fatty acids, dietary fiber and proteins. The chemical composition of chia seeds was reported as 15 to $25 \%$ protein, 30 to $33 \%$ oil, 18 to $30 \%$ dietary fiber, 26 to $41 \%$ carbohydrates and 4 to $5 \%$ vitamins and minerals. Most of the oil content is linolenic acid ( $\omega-3)$, about $60 \%$ of total oil content, and about $20 \%$ linoleic acid $(\omega-6)$ oil $[3,4,5]$.

Chia seed contain a rich pool of natural antioxidants [6, 7]. Among them, tocopherols, phytosterols, carotenoids and phenolic compounds, being the most common compounds present caffeic acid, rosmarinic acid, myricetin, quercetin, kaempferol, chlorogenic acid and 3,4-DHPEAEDA $[8,9]$.

The treatment of food by ionizing radiation to promote microbiological safety and conservation is one of the most extensively studied technology, being no questions about the safety and nutritional adequacy of irradiated foods $[10,11]$. Irradiation can also be used to obtain technological improvements in food materials [12].

The objective of this work was to evaluate the effect of gamma radiation, in doses of 0-20 kGy, on total phenolics extracted with two solvents in different compositions from chia seeds.

\section{MATERIALS AND METHODS}

\subsection{Material}

Chia seeds were supplied by Casa Forte Distribuidora de Produtos Alim. Ltda. 


\subsection{Irradiation}

About $600 \mathrm{~g}$ of chia seeds were submitted to irradiation process in simple polyethylene bags, in a ${ }^{60}$ Co source Gammacell 220, Atomic Energy of Canada Ltd (AECL), with doses of 0 (control), 5, 10 and $20 \mathrm{kGy}$. The nominal dose value in the experiments corresponds to the expected dose calculated with the certificated dose rate (Fricke dosimetry) and the radioactive decay law. The dose rate was $0.6 \mathrm{kGy} \mathrm{h}^{-1}$. The irradiated seeds were stored at room temperature.

\subsection{Chia extracts}

The chia extracts were grounded in a conventional mill. The seeds were defatted by mixing with $\mathrm{n}$-hexane in a proportion of 1:15 (w/v) and mechanically shacked for $6 \mathrm{~h}$ at room temperature. The samples were vortexed and the supernatants discarded. Extraction of phenolic compounds was carried out according Marineli et al [8] with some modifications. The phenolic compounds of chia defatted flour were extracted with ethanol/ water and methanol/ water ( $1 \mathrm{~g}$ of defatted chia flour/ 10 $\mathrm{mL}$ of solvent extract) in different proportions (Tab 1). The suspensions were mechanically shacked for $3 \mathrm{~h}$ at room temperature. The mixture was centrifuged at $3000 \mathrm{xg}$ for $15 \mathrm{~min}$ at $25^{\circ} \mathrm{C} \pm 1^{\circ} \mathrm{C}$. The supernatant was pipetted and maintained in dark at $-18^{\circ} \mathrm{C} \pm 1^{\circ} \mathrm{C}$.

Table 1: Water solution proportions of phenolic compounds extraction solvents.

\begin{tabular}{c|ccc}
\hline Sample & Ethanol & Methanol & Water \\
\hline A & 100 & 0 & 0 \\
B & 70 & 0 & 30 \\
C & 50 & 0 & 50 \\
D & 0 & 100 & 0 \\
E & 0 & 70 & 30 \\
F & 0 & 50 & 50 \\
\hline
\end{tabular}

\subsection{Total phenolic compounds}

The total phenolic content of chia seed extract was determined in triplicate, by Folin-Ciocalteu's method, based on Marineli et al [8], with some modifications, using gallic acid as a standard. In a vial, $50 \mu \mathrm{L}$ of extract, $800 \mu \mathrm{L}$ of distilled water and $25 \mu \mathrm{L}(0.25 \mathrm{~N})$ of Folin-Ciocalteu's reagent 
were mixed and incubated at room temperature for $3 \mathrm{~min}$ in the dark. Then, $100 \mu \mathrm{L}$ of sodium carbonate solution $(75 \mathrm{~g} / \mathrm{L}$ water) was added and further incubated for $2 \mathrm{~h}$ at room temperature. The absorbance was read at $725 \mathrm{~nm}$ in a microplate reader SpectraMax I3, Molecular Devices. A calibration curve was made using gallic acid $(5-1000 \mu \mathrm{g}$ gallic acid/L water) and the results were expressed in $\mu \mathrm{g}$ of gallic acid equivalent/ $\mathrm{mL}$ of sample extract ( $\mu \mathrm{gGAE} / \mathrm{mL})$.

\subsection{Statistical Analysis}

For the statistical analysis a software GraphPad Prism 8 was employed, using ANOVA followed of Turkey's test with significance of $p \leq 0,05$.

\section{RESULTS AND DISCUSSION}

Phenolic compounds exhibit free radical-scavenging activities, then, stability of polyphenols is crucial for the nutritional value of foods and is directly associated with their chemical structures. In order to evaluate the effect of gamma radiation on total phenolics from chia seeds, extracted with different compositions of solvents, a calibration curve, absorbance as a function of gallic acid concentration was prepared. The values of polyphenols were expressed in Fig 1 ( $\mu$ g of gallic acid equivalent/ $\mathrm{mL}$ of sample extract).

Figure 1: Total phenolic content of different extracts of irradiated chia seeds

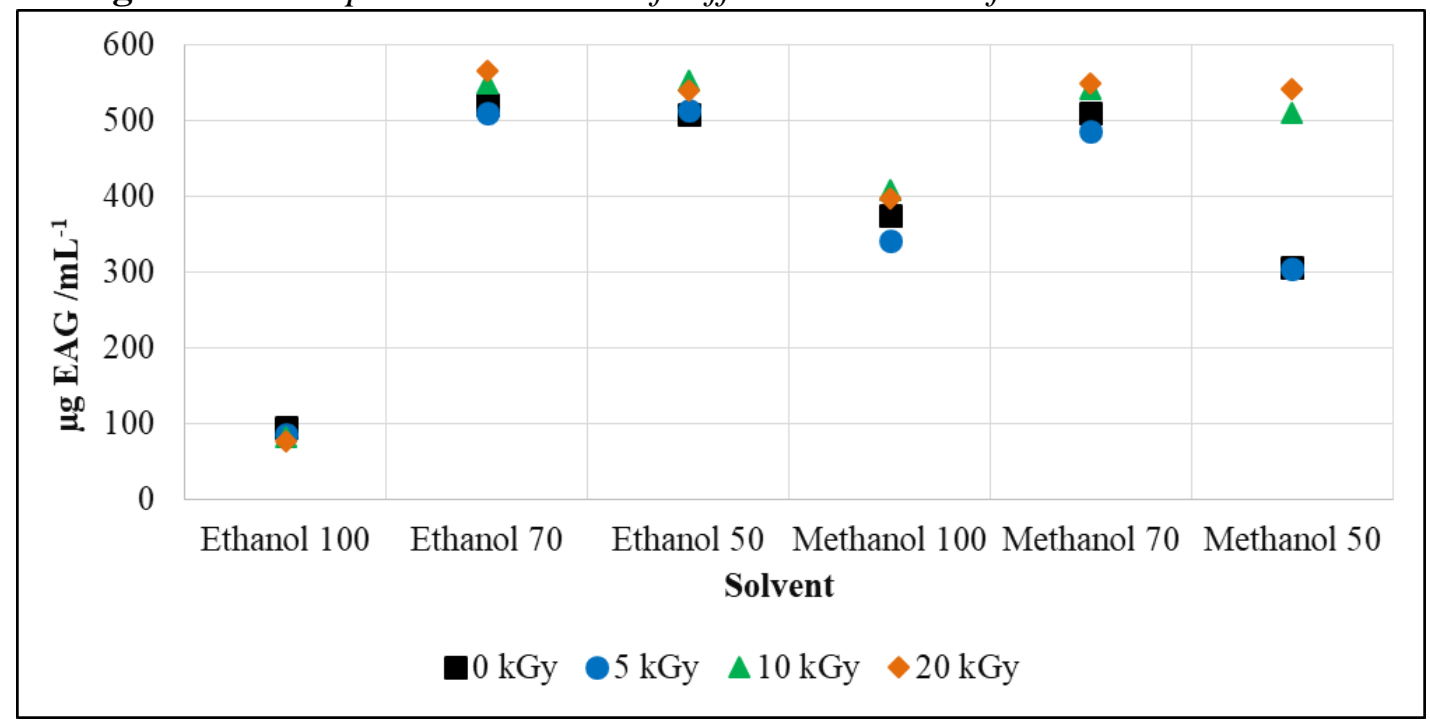


Analyzing the present results, irradiation treatment did not produce any decrease in total phenolic content extracted from defatted chia flour. Only methanol $50 \%$ was affected positively by the absorbed irradiation dose. The values of $\mu \mathrm{gGAE} / \mathrm{mL}$ were not affected by the absorbed irradiation dose on ethanol $100 \%$, ethanol $70 \%$, ethanol $50 \%$, methanol $100 \%$ and methanol $70 \%$.

Although standard solutions of phenolic compounds present relative thermal stability, few reports can be found in the literature trying to establish the effects of gamma and electron beam radiation on the chemical antioxidant profiles of different food products. Matsuda \& Mastro [13] reported that were significant difference on irradiated polyphenol-rich propolis extracts when compare with unirradiated sample.

The methanol $50 \%$ solvent increased total phenolic extraction when doses of 10 and $20 \mathrm{kGy}$ were applied. Even though there was difference among applied doses only on methanol $50 \%$, aqueous dilutions showed higher efficiency when compared with undiluted methanol or ethanol. Barbi [14] obtained similar results in terms of extraction solvents for chia defatted flour extracts. Independently of the solvent employed, results of increase of total phenolic content with increasing absorbed dose are also reported on literature in variety of samples such as, stored irradiated almond hull [15], fenugreek and spinach [16] or even on medicinal plants such Malva sylvestris L. [17]. Alcântara et al. [18] reported a higher efficient extraction of phenolic antioxidant compounds of chia samples with a mixture of solvents.

\section{CONCLUSION}

The total phenolic compounds extracted from irradiated chia seeds were not affected by irradiation when using as extraction solvents: ethanol $100 \%$, ethanol $70 \%$, ethanol $50 \%$, methanol $100 \%$ and methanol $70 \%$. On the other hand, a significant increase in polyphenolics was obtained with methanol $50 \%$, with highest doses; then, the nature of solvents affects the extraction yield from irradiated chia seeds. Water solutions showed higher extraction yield. Irradiation did not 
reduce the extraction yield in any of the systems assayed. In the present work a synergistic effect of radiation and the extraction process seems to appear. 


\section{ACKNOWLEDGMENT}

The authors want to express thanks to Eng. Elizabeth S. R. Somessari for the guidance in the irradiation operation. Casa Forte Distribuidora de Produtos Alim. Ltda. For samples supply. In addition, the author acknowledged CAPES, CNPq and IPEN-CNEN/SP for institutional support.

\section{REFERENCES}

[1] ÖZCAN, M. M.; AL-JUHAIMI, F. Y.; AHMED, I. A. M.; OSMAN, M. A.; GASSEM, M. A. Effect of different microwave power setting on quality of chia seed oil obtained in a cold press. Food Chemistry, v. 278, p. 190-196, 2019.

[2] COATES, W.; AYERZA, R. Production potential of chia in northwestern Argentina. Industrial Crops and Products, v. 5, p. 229-233, 1996.

[3] MigliaVACCA, R.A.; SIlVA, T. R. B.; VASCONCElOS, A. L. S.; FILHO, W. M.; BAPTISTELlA, J. L. C. O cultivo da chia no Brasil: Futuro e perspectivas. Journal of Agronomic Sciences, v. 3, p. 161- 179, 2014.

[4] UTPOTT, M. Utilização da mucilagem da chia (Salvia hispanica L.) na substituição de gordura e/ou gema de ovo em maionese. Universidade Federal do Rio Grande do Sul. Instituto de Ciências e Tecnologia de Alimentos. Trabalho de Conclusão de Curso, Engenharia de Alimentos, 2012.

[5] MOHD ALI, N.; YEAP, S. K.; YONG HO, W.; BEH, B. K.; TAN, S. W.; GUAN, S. T. The Promising Future of Chia, Salvia hispanica L.. Journal of Biomedicine and Biotechnology, v. 2012, p. 1-9, 2012.

[6] ÁlVAREZ-CHAVEZ, L. M.; VAldiVIA-LOPEZ, M. A.; ABURTO-JUAREZ, M. L. ; TECANTE,. A. Chemical characterization of the lipid fraction of mexican chia seed (Salvia hispanica L.). International Journal of Food Properties, v. 11, p.687-697, 2008.

[7] IXTAINA, V. Y.; MARTINEZ, M. L.; SPOTORNO, V.; MATEO, C. M.; MAESTRI, D. M.; DIEHL, B. W. K.; NOLASCO, S. M.; TOMÁS, M. C. Characterization of chia seed oils 
obtained by pressing and solvent extraction. Journal of Food Composition and Analysis, v. 24, p. 166-174, 2011.

[8] MARINELI, R. S.; MORAES, E. A.; LENQUISTE, S. A.; GODOY, A. T.; EBERLIN, M. N.; MARÓSTICA Jr., M. R. Chemical characterization and antioxidant potential of Chilean chia seeds and oil (Salvia hispanica L.). LWT - Food Science and Technology, v. 59, p. 13041310, 2014.

[9] OLIVEIRA-ALVES, S.C.; VENDRAMINI-COSTA， D. B.; CAZARIN, C. B. B.; MARÓSTICA Jr., M. R,; FERREIRA, J. P. B.; SILVA A. B.; PRADO, M. A.; BRONZE, M. R. Characterization of phenolic compounds in chia (Salvia hispanica L.) seeds, fiber flour and oil. Food Chemistry, v. 232, p. 295-305, 2017.

[10] MASTRO, N. L. D. A radiação ionizante na promoção da alimentação adequada e saudável. Vigilância Sanitária em Debate, 2015.

[11] FELICIANO, C. P. High-dose irradiated food: Current progress, applications, and prospects. Radiation Physics and Chemistry, v. 144, p. 34-36, 2018.

[12] MASTRO, N. L. del. Role of irradiation in the food industry. International Journal of Nuclear Governance Economy and Ecology, v. 3, p. 266-273, 2011.

[13] MATSUDA, A. H., MASTRO, N. L. del. Stability of phenolic compounds of the propolis processed by ionizing radiation. INTERNATIONAL NUCLEAR ATLANTIC CONFERENCE, 2002, Rio de Janeiro. Annals, Rio de Janeiro: Comissão Nacional de Energia Nuclear, p. 3080, 2002.

[14] BARBI, R. C. T. Extração e quantificação de compostos fenólicos e antioxidantes da chia (Salvia hispânica L) usando diferentes concentrações de solventes. Universidade Tecnológica Federal do Paraná. Trabalho de Conclusão de Curso, Engenharia de Alimentos, 2016.

[15] MOOSAVI, K. S.; HOSSEINI1, S.; DEHGHAN, G.; JAHANBAN-ESFAHLAN, A. the effect of gamma irradiation on phytochemical content and antioxidant activity of stored and none stored almond (Amygdalus communis L.) hull. Pharmaceutical Sciences, v. 20, p. 102-106, 2014.

[16] HUSSAIN, P. R.; SURADKAR, P.; JAVAID, S.; AKRAM, H.; PARVEZ, S. Influence of postharvest gamma irradiation treatment on the content of bioactive compounds and antioxidant 
activity of fenugreek (Trigonella foenum-graceum L.) and spinach (Spinacia oleracea L.) leaves. Innovative Food Science \& Emerging Technologies, v. 33, p. 268-281, 2016.

[17] SALEM, I. B. Effect of ionizing radiation on the microbiological safety and phytochemical properties of cooked Malva sylvestris L. BioMed Research International, v. 2018, 2018.

[18] ALCANTARA, M. A.; POLARI, I. L. B.; MEIRELES B. R. L. A.; LIMA A. E. A.; SILVA Jr, J. C.; VIEIRA, E. A.; SANTOS, N. A.; CORDEIRO, A. M. T. M. Effect of the solvent composition on the profile of phenolic compounds extracted from chia seeds. Food Chemistry, v. 275, p. 489-496, 2019. 